MAREK GENSLER

Instytut Filozofii

Uniwersytetu Łódzkiego

\title{
SATYRA NA LENIWYCH TEOLOGÓW, CZYLI O PEWNYCH LEKCJACH Z FILOZOFII NIEODROBIONYCH OD SZEŚCIUSET LAT
}

W prowadzonych ostatnio z narastającą intensywnością sporach etycznych i obyczajowych w Polsce ze strony liberalno-sekularystycznej często daje się słyszeć taki argument: ,poglądy naszych przeciwników wypływają z pobudek religijnych i dlatego nie powinny być narzucane całemu społeczeństwu, które w części jest świeckie". Na ten zarzut strona tradycyjno-katolicka zazwyczaj odpowiada mniej więcej tak: „Ależ nasze stanowisko, niezależnie od tego, że wypływa z objawienia, da się także wyprowadzić rozumowo z dostępnego dla każdego źródła, mianowicie z natury ludzkiej, i w związku z tym może, a właściwie powinno być podzielane także przez osoby, które, by zacytować preambułę Konstytucji, «wartości wyprowadzają z innych źródeł»”. Po czym, w zależności od poziomu erudycji lub okazji, następują odwołania do św. Tomasza, Arystotelesa, Sokratesa lub do samego delfickiego Apollona, na drzwiach świątyni którego widniał napis gnōthi seauton, czyli poznaj samego siebie. Jest rzeczą godną uwagi, że te odwołania do wspólnego dziedzictwa rozumu niezwykle rzadko wychodzą poza wiek XIII. A przecież nie oznacza to, że potem filozofia chrześcijańska, przynajmniej w swojej katolickiej odmianie, nie stworzyła już niczego wartościowego. Dlaczego zatem pozostaje przy arystotelesowsko-neoplatońskim języku św. Tomasza z Akwinu, coraz mniej zrozumiałym dla współczesnego człowieka, ukształtowanego przez antymetafizycznie nastawione nauki przyrodnicze? Taka postawa sprawia, że o porozumienie ze światem świeckim jest coraz trudniej i niemała grupa osób z obu stron podziału widzi postępy modernizacji jednocześnie jako postępy dechrystianizacji, rzecz jasna wyciągając z tego przeciwstawne 
wnioski. Czy rzeczywiście mamy tu do czynienia z jakimś historycznym determinizmem? Przyjrzyjmy się tej kwestii dokładniej.

Nie ulega wątpliwości, że od samego swego początku (jak zaświadcza Prolog do Ewangelii św. Jana swoim odwołaniem do Logosu) chrześcijaństwo poszukiwało $\mathrm{w}$ filozofii odpowiedniego narzędzia do przedstawiania swej doktryny. Oferta szkół filozoficznych była szeroka, ale chrześcijańscy autorzy bardzo szybko opowiedzieli się za jedną z nich: platonizmem ${ }^{1}$. Doskonale ilustruje to historia Justyna Męczennika, apologety z II w., który, jak sam pisze, poszukiwał prawdy w różnych szkołach, zanim spotkał Prawdę wcieloną, a przedostatnim, wskazującym kres, przystankiem jego intelektualnej podróży była doktryna Platona ${ }^{2}$. To myśl Platona odkryła przed nim wieczny, niezmienny i doskonały świat transcendencji, kierując go na drogę do Absolutu, w którym ostatecznie zobaczył chrześcijańskiego Boga. Kolejny, bardzo charakterystyczny przykład stanowi szkoła katechetyczna w Aleksandrii, która położyła fundamenty pod chrześcijańską teologię: założona przez Klemensa Aleksandryjskiego, który chlubił się tym, że jego nauczyciele wiary byli uczniami apostołów ${ }^{3}$, jest jednocześnie pierwszym ośrodkiem chrześcijańskiej recepcji Platona (choć Klemens, tworząc swoją gnozę chrześcijańską, korzysta z dorobku niemal całej kultury helleńskiej), a uczeń Klemensa, Orygenes, kształci się w tej samej filozoficznej atmosferze co Plotyn, pogański odnowiciel platonizmu i prawdopodobnie jego kolega z wykładów Ammoniusza Sakkasa, aleksandryjskiego Sokratesa, który wielu młodych ludzi skierował ku tej filozofii ${ }^{4}$. Przykłady te pokazują, że chrześcijanie bardzo szybko potrafili odnaleźć filozoficzny język, który z jednej strony pozwolił im samym wyrazić treści zawarte w swojej wierze, a z drugiej strony umożliwił im komunikowanie tych treści także tym, którzy jeszcze się z nią nie spotkali.

Przyjmując neoplatonizm jako swój ,język ojczysty”, wczesne chrześcijaństwo szybko stało się neoplatońskie do szpiku kości, tzn. w swoim nauczaniu umiało ujmować i badać wszystkie i tylko te treści, które dało się w tym języku wyrazić. Konsekwencją takiego podejścia było pomijanie wszystkiego tego, co choć obecne w przekazie biblijnym, nie-

${ }^{1}$ Pojawiały się także próby budowania nauki chrześcijańskiej na podstawie innych założeń filozoficznych - najbardziej znana jest autorstwa Tertuliana, odwołująca się do stoickiego materializmu - ale były izolowane i krótkotrwałe. Cf.É. Gilson, Historia filozofii chrześcijańskiej w wiekach średnich, Warszawa 1987, s. 516.

2 Justyn Męczennik, Dialog z Żydem Tryfonem, 2-8; cyt. za: B. Altaner, A. Stuiber, Patrologia, Warszawa 1990 (oryg. niem. 1978), s. 129.

${ }^{3}$ Klemens Aleksandryjski, Kobierce zapisków filozoficznych dotyczacych prawdziwej wiedzy, Warszawa 1994, s. 8-9.

${ }^{4}$ Porfiriusz, 0 życiu Plotyna oraz o układzie jego ksiag, w: Plotyn, Enneady, cz. 1-3, Warszawa 2000, s. 64. 
zgodne było z filozoficznymi zasadami platonizmu. Najwyraźniej widać to w koncepcji człowieka. Czysto platońskie ujęcie, widzące w ciele więzienie, w którym dusza odbywa pokutę za grzechy popełnione w poprzednim życiu, nie mogło zostać przyjęte, z uwagi na odrzucenie przez ortodoksyjnych chrześcijan koncepcji preegzystencji dusz i będącej jej konsekwencją metempsychozy. Nie oznaczało to jednak, że odrzucona została nauka widząca w ciele coś zewnętrznego i przygodnego względem człowieka, utożsamionego odtąd $\mathrm{z}$ duszą ${ }^{5}$. Wybierając platonizm, chrześcijaństwo zdecydowało się porzucić afirmację cielesności, właściwą dla judaizmu, z którego się wywodziło. Ciało stało się dla duszy narzędziem, ważnym o tyle, o ile mogło służyć jej poprawie bądź zgubie, ale nieinteresującym jako coś samo w sobie. A jeśli nieciekawe staje się własne ciało, o ileż mniej ciekawa musi stać się reszta przyrody, do której to ciało należy. „Chcę poznać Boga i duszę, i nic więcej"6 deklaruje na początku swych Solilokwiów św. Augustyn. To jego autorytet sprawi, że do XIII w. refleksja nad przyrodą będzie ograniczona niemal wyłącznie do kosmogonicznych rozważań inspirowanych biblijnym „dziełem sześciu dni”, a komentowanych często z pomocą platońskiego Timajosa ${ }^{7}$. Natura po upadku traci zupełnie swój powab jako to, co mniej doskonałe, poddane konieczności, a w dodatku zepsute.

Znaczącą zmianę przynosi odkrycie i przyswojenie sobie przez łacińskie chrześcijaństwo filozofii Arystotelesa.Jej język, empiryzm i indukcyjna metoda są tak różne od tego, do czego przywykli łacińscy uczeni, że trzeba było dwóch pokoleń, by nauczyli się nimi posługiwać, przełamując lęk przed duchowymi zagrożeniami, jakie mogą płynąć z tej pogańskiej doktryny $^{8}$. Tym, co pomaga im przełamać obawy, jest nie tylko przekonanie o poznawczej wartości myśli Arystotelesa, już wcześniej, nieco na wyrost, uznawanego za wielki autorytet, ale także to, że jej język okazuje się ostatecznie przekładalny na zrozumiałe dla łacinników neoplatońskie narzecze. Połowa XIII w. to czas współpracy znamienitej pary translatorskiej: Wilhelm z Moerbeke nadaje tekstom Stagiryty klarowną łacińską postać (wcześniejsze tłumaczenia, zwłaszcza te za pośrednictwem arabskiego, były bardzo niejasne), a Tomasz z Akwinu przejrzyście tłumaczy, o co w nich

${ }^{5}$ Koncepcja preegzystencji duszy pojawia się jeszcze w 0 zasadach Orygenesa, ale późniejsi ojcowie greccy i łacińscy już do niej nie wracają; cf. B. Altaner, A. Stuiber, op. cit., s. 292-293.

${ }^{6}$ Cf. Augustyn, Solilokwia, II-7, w: św. Augustyn, Dialogi filozoficzne, oprac. W. Seńko, Kraków 1999, s. 240.

${ }^{7}$ Doskonałym przykładem jest tu traktat De sex dierum operibus Teodoryka z Chartres. Cf. S. Bafia, Teodoryk z Chartres. Wprowadzenie, w: Wszystko to ze zdziwienia. Antologia tekstów filozoficznych z XII wieku, red. M. Frankowska-Terlecka, Warszawa 2006, s. 104-108.

${ }^{8}$ Cf.É. Gilson, op. cit., s. 222-224. 
chodzi ${ }^{9}$. Jest to możliwe dlatego, że arystotelizm łaciński jest otwarty na neoplatonizm, dziedziczy bowiem także pochodzącą z późnej starożytności tradycję interpretacyjną szkoły aleksandryjskiej, która to tradycja dotarła na Zachód w dużej mierze za pośrednictwem myślicieli arabskich, a zwłaszcza Awicenny ${ }^{10}$. Arystotelesowskie gatunkowe formy poznawcze, nawet jeśli wyprowadzane są dzięki abstrakcji z poznania zmysłowego, uzyskują dzięki intelektowi czynnemu pewność, właściwą poznaniu idei z tradycji platońskiej. W ten sposób ogólne natury, choć przez poszczególne podmioty myślące poznawane są na sposób indukcyjny, odzwierciedlają powszechne natury rzeczy, które same z siebie bytują wprawdzie tylko potencjalnie, ale bytując w akcie już to jako konkretne jednostki, już to jako ogólne pojęcia, gwarantują prawdziwość tych ostatnich.

Neoplatońska interpretacja sprawia, że trzynastowieczni scholastycy mimo przyjęcia empiryzmu, głoszącego że „nie ma niczego w intelekcie, co wcześniej nie byłoby w zmysłach" ${ }^{11}$, nadal widzą naukę jako wiedzę o gatunkowych naturach, które są pewnym rodzajem bytu, posiadającym znaczące podobieństwo do platońskich idei, wyrażające się w dwóch podstawowych cechach: są ogólne i niezmienne. Oznacza to, że przedmiotem wiedzy są byty ogólne; choć nie są to platońskie idee bytujące aktualnie w innym, inteligibilnym świecie, są to ogólne natury bytujące potencjalnie, ale będące bytową podstawą zarówno rzeczy, jak i pojęć, gwarantując tym samym ich odpowiedniość. Wskutek takiego podejścia do filozofii Arystotelesa wiedza o człowieku scholastycznych uczonych rozszerza się wprawdzie na rozmaite zagadnienia jego cielesności obejmujące zarówno anatomię, jak i fizjologię, skoro uznają oni, że człowiek jest bytem cielesno-duchowym, ale jest nadal wiedzą o „naturze ludzkiej”, widzianej jako jeden ogólny byt, którego jednostki są przygodnymi, mniej lub bardziej doskonałymi realizacjami. Rozwiązanie to pozwala wszakże rozszerzyć refleksję teologiczną na obszary, gdzie język neoplatonizmu nie pozwalał dotąd wkraczać lub znacząco utrudniał precyzyjne ujęcie problemu, takie jak zmartwychwstanie ciał

${ }^{9}$ Tomasz z Akwinu skomentował niemal wszystkie dzieła Arystotelesa, korzystając z tłumaczeń Wilhelma z Moerbeke, ale informacja, że byli przyjaciółmi i Wilhelm tłumaczył Arystotelesa dla Tomasza na jego prośbę, pochodzi z czasów późniejszego średniowiecza; cf. B.G. Dod, Aristoteles Latinus, w: The Cambridge History of Later Medieval Philosophy, red. N. Kretzmann, A. Kenny, J. Pinborg, Cambridge 1982, s. 63.

${ }^{10} \mathrm{Cf}$. Ch. Burnett, Arabic into Latin: The Reception of Arabic Philosophy into Western Europe, w: Cambridge Companion to Arabic Philosophy, red. P. Adamson, R.C. Taylor, Cambridge 2005, s. 371 .

${ }^{11} \mathrm{Cf}$. Arystoteles, Analityki wtóre, w: idem, Dzieła wszystkie, t. 1, Warszawa 1990, II, 20, 100a 10. 
czy przeistoczenie eucharystyczne ${ }^{12}$. Tam, gdzie św. Augustyn musiał wikłać się w tłumaczenia, że zmartwychwstałe ciało w zasadzie będzie zupełnie odmienione i dlatego zmartwychwstanie będzie dla człowieka korzyścią, Henryk z Gandawy może odpowiedzieć po prostu, tak jak Tomasz z Akwinu, że bez ciała człowiek jest niedoskonały.

Przekonanie o tym, iż właściwym przedmiotem nauki są ogólne natury, sprawia, że łatwo z tak konstruowanej wiedzy teoretycznej wyprowadzać tezy normatywne. Aczkolwiek nie wydaje się to logiczną koniecznością, jest na tyle intuicyjne, że Arystoteles nie widział powodów, aby to tłumaczyć. „Prawo naturalne” jest w tej koncepcji postacią prawa natury, właściwą dla tej jej cząstki, jaką jest gatunek ludzki, i tak samo jak prawa mechaniki wyznaczają zasady, wedle których dokonują się zmiany w świecie nieożywionym, tak też prawo naturalne wyznacza zasady ludzkiego postępowania. Odkrywane jest ono także na dokładnie tej samej drodze poznania natury rzeczy, tzn. poznania jej zasad. Dla przyrody nieożywionej zasadami tymi są elementy, dla człowieka - jego dusza złożona z, hierarchicznie uporządkowanych, części rozumnej, zmysłowej i wegetatywnej. To, czym człowiek jest jako natura, staje się wzorcem tego, czym powinien być jako jednostka, ponieważ natura pozbawiona jest przygodnych ograniczeń przytrafiających się jednostkom ${ }^{13}$. A skoro jest tylko jedna natura, to i jeden wzorzec. Takie rozwiązanie w prosty sposób prowadzi do fetyszyzacji tego, co dominujące (niekoniecznie statystycznie) ${ }^{14}$, i przedstawienia go jako niezmiennej natury, której nadaje się religijną sankcję „Bożego planu”. W przypadku człowieka tym „odwiecznym wzorcem”, doskonale wypełniającym ludzką naturę, staje się dojrzały fizycznie i umysłowo mężczyzna, zdolny do przedłużenia gatunku (zadanie cielesne) i osiągnięcia szczęścia (zadanie duchowe). Kobiety, dzieci, niepełnosprawni, homoseksualiści są w tym ujęciu ludźmi niedoskonałymi lub zdefektowanymi. Taka interpretacja Arystotelesa, nota bene nie bardzo odległa od jego własnych wyobrażeń na temat człowieka ${ }^{15}$, została przez Tomasza z Akwinu uczyniona częścią jego filozoficzno-teologicznego systemu, który od końca XIII w.

12 Przykładem mogą tu być dwie kwestie kwodlibetalne Henryka z Gandawy: Czy możliwe jest zmartwychwstanie ciał ludzkich? oraz Czy może zachodzić jakaś przemiana nie majaca podłoża w materii?; cf. Wszystko to ze zdziwienia. Antologia tekstów filozoficznych z XIII wieku, red. K. Krauze-Błachowicz, Warszawa 2002, s. 379-387.

${ }^{13}$ Cf. Tomasz z Akwinu, Traktat o cnotach. Suma teologii I-II, 49-67, oprac. W. Galewicz, Kęty 2006, kw. 63, art. 1: „Czy cnota przysługuje nam z natury?”, s. 200-201.

${ }^{14}$ Zakładając, że najlepiej naturę ludzką realizują ludzie wypełniający jej definicyjną treść: „,zwierzę rozumne”, można mieć wątpliwości, czy takie jednostki stanowią większość populacji. Arystoteles był przekonany, że nie, co nie przeszkadzało mu twierdzić, że to właśnie one są najlepszą częścią gatunku ludzkiego.

${ }^{15}$ Arystoteles z natury wyprowadza państwo i stosunki społeczne, naturę nato- 
(a szczególnie od kanonizacji Tomasza w 1323 r.) coraz silniej wpływał na doktrynę Kościoła katolickiego.

Tymczasem to właśnie na początku XIV w., na krótko przed kanonizacją Tomasza, miało miejsce wydarzenie, które sprawiło, iż pojęcia, w tym pojęcie natury, nabrały zupełnie innego charakteru niż wcześniej. To jego odległą konsekwencją stała się współczesna trudność ze znalezieniem języka porozumienia między stronami sporów o człowieka i jego naturę. Właśnie w tym czasie młody angielski franciszkanin, sposobiący się do studiów teologicznych w Oxfordzie, Wilhelm Ockham na nowo zreinterpretował filozofię Arystotelesa, rozbijając jej dotychczasową, powszechnie przyjmowaną, wizję: jego zdaniem konsekwentne stosowanie się do zasad empirystycznej teorii poznania prowadzi nas jedynie do ogólnych pojęć, a nie do ogólnych natur. Na czym konkretnie polega różnica między wcześniejszą, realistyczną, a Ockhamową interpretacją Arystotelesa? Na wprowadzeniu do filozofii odnowionego nominalizmu.

Nominalizm Ockhama nazywamy odnowionym, ponieważ nie był on pierwszym myślicielem, który zauważył, że przyjęcie, iż poznanie ogólne, jakie uzyskujemy na drodze empirycznej, niesie ze sobą pewne, nieprzewidziane przez samego Arystotelesa, konsekwencje dotyczące przedmiotu tego poznania. W historii nauki nominalizm pojawiał się trzy razy i dopiero za trzecim razem pozostał, chyba już na trwałe, jako jeden z elementów metody naukowej (choć może nie tak silnie eksponowany jak eksperyment). Pierwsza, jak się okazało przedwczesna, próba nominalistycznego ujęcia kwestii statusu pojęć ogólnych miała miejsce w XII w. Pod wpływem inspiracji swego nauczyciela, Roscelina z Compiègne ${ }^{16}$, Piotr Abelard, przedstawił nowy pogląd na ten temat, wskazując, że, najprościej mówiąc, jeśli nasze pojęcia ogólne pochodzą z poznania jednostkowych bytów, to orzekają także o jednostkowych bytach, tyle że w sposób na tyle nieostry, że jedno i to samo pojęcie może być orzekane o wielu różnych pod innymi względami bytach ${ }^{17}$; np. pojęcie kot, wyprowadzone z poznania różnych Mruczków, może być prawdziwie orzekane także i o innych Filonkach niezależnie od tego, czy są łaciate, pręgowane czy gładkie, duże czy małe, itp.

miast ustala tak: „Gdy chodzi o ustalenie zgodności z naturą [należy] brać pod uwagę stan normalny, a nie wykolejenia. Dlatego przedmiotem rozważania winien być człowiek najzupełniej zdrów na ciele i duszy". Arystoteles, Polityka, w: idem, Dzieła wszystkie, t. 6, oprac. M. Chigierowa et al., Warszawa 2001, s. 30 (1254a 28-30). Temu zagadnieniu poświęcony jest szerszy fragment: $1252 \mathrm{~b}-1255 \mathrm{~b}$.

${ }^{16}$ Roscelina uważa się często za pierwszego nominalistę, ale ponieważ jego poglądy znamy z krótkich omówień z drugiej ręki, to Abelardowy wykład z 0 pojęciach ogólnych wyznacza początek tej koncepcji. Cf. É. Gilson, op. cit., s. 142 i 569.

17 P. Abelard, Rozprawa o pojęciach ogólnych, w: idem, Rozprawy, oprac. L. Joachimowicz, Warszawa 1969, s. 666. 
Aczkolwiek żaden z jego współczesnych przeciwników (a miał ich wielu) nie potrafił podważyć przedstawionych przez Abelarda racji, nominalizm nie doczekał się wówczas kontynuacji; zapewne był trudny do zrozumienia przez wyrosłych na gruncie augustynizmu ludzi, dla których już sam empiryzm był dziwaczną nowinką. Dla ludzi takich jak Bernard z Clairvaux, główny oponent Abelarda, wiedza dotyczyła wrodzonych idei, które dusza odkrywała w swoim wnętrzu, jeśli odpowiednio się do tego przygotowała przez praktykowanie cnót, modlitwę i kontemplację. Próby zdobycia wiedzy na innej drodze były dowodem na grzeszną pychę rozumu ${ }^{18}$.

Trzeba było ponad stu lat zaznajamiania się z dorobkiem Arystotelesa, by nominalistyczna koncepcja powszechników, tym razem ogłoszona właśnie przez Ockhama, trafiła na podatny grunt. Nominalizm znalazł licznych zwolenników nie tylko w Anglii, ale także we Francji ${ }^{19}$, którą podbił z impetem mogącym zawstydzić Henryka V. Co ciekawe, rozwijał się nie tylko na wydziałach sztuk wyzwolonych, ale także na teologii, co zresztą zgodne było z intencją samego Ockhama, przekonanego, że jego koncepcja odnosi się do wszelkiego poznania naukowego ${ }^{20}$. Przyjęcie, że nasza wiedza ma charakter hipotetyczny, ośmieliło myślicieli, którzy rozwinęli koncepcję eksperymentu myślowego (w braku technicznych możliwości oraz chęci organizowania eksperymentów rzeczywistych), wprowadzając do filozofii i teologii tzw. procedury secundum imaginationem ${ }^{21}$. Oderwanie refleksji nad pojęciami od rzeczy umożliwiło lepszą analizę samych procesów, czego skutkiem było np. utworzenie przez Ockhama pojęcia przyspieszenia przy okazji refleksji nad ruchem lokalnym (zmianą miejsca). Nominalizm, zwany odtąd via moderna, bez przeszkód rozwijał się niemal do końca XV w., przez jakiś czas górując nawet nad realizmem, który otrzymał miano via antiqua. Być może nie przypadkiem przypadło to na przełom XIV i XV w., kiedy pojawiające się w okresie wielkiej schizmy herezje Jana Wycliffa, a potem Jana Husa, gorliwie zwalczanych przez paryskiego nominalistę Jana Gersona, opowiadały się za realistycznym rozumieniem powszechników ${ }^{22}$.

${ }^{18}$ Bernard poświęcił temu zagadnieniu osobne dzieło, O stopniach pokory i pychy. Cf. Bernard z Clairvaux, 0 stopniach pokory i pychy, w: idem, 0 miłowaniu Boga, Poznań 2000, s. 65-122.

${ }^{19} \mathrm{~Np}$. Jana Buridana i jego uczniów. Cf. E. Jung-Palczewska, Wstęp, w: Wszystko to ze zdziwienia. Antologia tekstów filozoficznych z XIV wieku, red. eadem, Warszawa 2000, s. XXXV-XXXIX.

${ }^{20} \mathrm{Cf}$. W. Ockham, O nauce w ogóle, a nauce przyrodniczej w szczególności, w: Wszystko to ze zdziwienia. Antologia tekstów filozoficznych z XIV wieku, s. 214-215.

${ }^{21}$ Cf. E. Jung-Palczewska, Między filozofia przyrody a nowożytnym przyrodoznawstwem. Richard Kilvington i fizyka matematyczna w średniowieczu, Łódź 2002, s. 39.

${ }^{22} \mathrm{Na}$ temat krytyki Gersona praskich zwolenników Wycliffa, Husa i Hieronima z Pragi cf. Z. Kaluza, Le chancelier Gerson et Jérôme de Prague, w: idem, Études doctrinales sur le XIVe siècle. Théologie, logique, philosophie, Paris 2013, s. 208-211, 231. 
Pod koniec XV w. nominalizm, jak cała scholastyka, osłabł, a jego epigoni próbowali raczej daremnie „wzbogacać” go próbami powiązania z via antiqua w celu stworzenia mającej przezwyciężyć kryzys via communis ${ }^{23}$. Tym, co przyniosło mu kres, był odwrót od arystotelizmu, spowodowany krytyką całej scholastyki wychodzącą z jednej strony od zwolenników nowej pobożności, z drugiej zaś od humanistów pozostających pod wpływem odrodzonego, od drugiej połowy XV w. (w dużej mierze dzięki tłumaczeniom i pracom Marsilia Ficino), platonizmu. Zarzutom ze strony takich autorów jak Mikołaj z Kuzy czy Erazm z Rotterdamu nikt nie potrafił przeciwstawić podobnie silnych racji, tym bardziej że walczyli także najstraszliwszą bronią - śmiechem ${ }^{24}$. Nic więc dziwnego, że odrodzenie refleksji nad światem oraz próby reformy filozofii na początku XVII w. zapoczątkowane przez Kartezjusza dokonało się na gruncie realistycznym, czerpiąc z myśli św. Augustyna, należącej do tradycji platońskiej.

Ostateczny powrót do nominalizmu nastąpił w XVIII w. Jego sprawcą był David Hume, który po raz kolejny doprowadził empiryzm, tym razem angielski, wywodzący się bezpośrednio od Johna Locke'a, do jego antyrealistycznej postaci, negując bytową realność już nie tylko substancji ogólnych, ale substancji w ogóle. Jego zdaniem, najprościej rzecz ujmując, jeśli nie znajdujemy czegoś takiego jak substancja in sensu (a nie znajdujemy, bo zmysły informują nas tylko o jakościach), to nie ma ona prawa pojawić się in intellectu, a jeśli tam jest - to prawem kaduka, jako skutek przyzwyczaje$n^{2}{ }^{25}$. Nasza wiedza zatem nie może rościć sobie prawa do pewności: mó-

23 „Będące od r. 1483 w upadku Kolegium Montaigu (Montis acuti) ok. 1506 dochodzi do rangi najżywotniejszego w Paryżu i już na przełomie wieków staje się jedną z głównych twierdz ockhamizmu o zabarwieniu szkotystycznym". S. Swieżawski, Dzieje filozofii europejskiej XV wieku, t. 1, Warszawa 1974, s. 142. Dziękuję Dawidowi Nowakowskiemu za wskazanie tej informacji.

${ }^{24}$ Obydwaj główne źródło jałowości scholastyki widzą w jej przesadnym przywiązaniu do logiki, sprawiającym, że treści stają się czymś mniej ważnym niż forma. Erazm pozwala sobie na złośliwości: „Niektórzy ludzie, poprzestając beztrosko na samej tylko dialektyce, uważają się za dostatecznie przygotowanych do rozprawiania na każdy temat. Przywiązują oni do tej umiejętności tak wielkie znaczenie, że sądzą, iż koniec byłby z wiarą chrześcijańską, gdyby nie oparła się na pomocy dialektyki [- - ]. Umiejętność logicznego myślenia pochwala naturalnie i Augustyn, byle tylko nie towarzyszyła jej typowa dla niej choroba: upór w walce i żądza sporów. Ale - pytam się - po cóż dokonywać podziałów i ustalać definicje, po co wyprowadzać wnioski,jeśli nie znasz właściwości ani istoty rzeczy, o której mowa? Co ci z tego, że rozprawiając o krokodylu ułożyłeś sprawnie sylogizm typu Celarent czy Baroco, jeśli nie wiesz, jakiego to rodzaju drzewo czy zwierzę ten krokodyl?". Erazm z Rotterdamu, Metoda prawdziwej teologii, w: idem, Trzy rozprawy, oprac. J. Domański, Warszawa 2000, s. 185.

${ }^{25}$ Cf. D. Hume, A Treatise of Human Nature, Harmondsworth 1985, ks. I, „Of the idea of existence and of external existence", s. 114-116. 
wiąc paradoksalnie, jest z natury hipotetyczna. Zapoczątkowany przez niego nominalizm trwa po dziś dzień, mimo silnej zrazu reakcji przeciw niemu przedstawionej przez Immanuela Kanta i kontynuowanej w różnych postaciach niemieckiego idealizmu ${ }^{26}$.Został on przyjęty przede wszystkim przez nauki ścisłe i razem $z$ metodą matematyczną oraz eksperymentem stanowi część ich metodologicznego fundamentu. Nie został natomiast przyjęty przez teologię: deistyczne czy wręcz ateistyczne poglądy, które już sam Hume wyprowadzał ze swojego nominalizmu, były dla teologów nie do przyjęcia, a ich odrzucenie położyło się cieniem na stosunku do samego nominalizmu. To zapewne, obok niechęci do uznania głoszonego przez nominalistów hipotetycznego jedynie charakteru wiedzy, było jedną z przyczyn, dla których przy odnawianiu teologii katolickiej, zainspirowanym przez Leona XIII, sięgnięto po starą, sprawdzoną, realistyczną doktrynę św. Tomasza $\mathrm{z}$ Akwinu ${ }^{27} \mathrm{i}$ na ponad sto lat zyskała ona monopol, czasem zaciekle broniony, na tłumaczenie zasad wiary i ich relacji do ludzkiej rzeczywistości. Zapewne niezamierzoną konsekwencją tego wyboru stało się swoiste pomieszanie języków, sprawiające, że teolodzy i naukowcy (oraz część filozofów) przestali się wzajemnie rozumieć. Swoistym paradoksem tej wieży Babel było to, że łatwiej było teologom o dialog z marksistami, podobnie jak oni przekonanymi o obiektywnym charakterze wiedzy (bo wywodzącymi się z tradycji wyrosłej w opozycji do Hume'a klasycznej filozofii niemieckiej, należącej zatem do tej samej, platońskiej linii rozwojowej), niż nawet najżyczliwiej do religii usposobionym przedstawicielami tradycji empirystycznej, takimi chociażby jak pragmatysta William James, który nie widział ani potrzeby, ani możliwości ujmowania przekonań religijnych jako czegoś więcej niż hipotezy ${ }^{28}$.

${ }^{26}$ Immanuel Kant we wstępie do Krytyki czystego rozumu desperacko pyta: „Cóż jest przeto powodem, że nie można tu było jeszcze znaleźć pewnej [podkr. moje M.G.] drogi badania naukowego? Czyż jest ona może niemożliwa?”. B XV , 8-10. Cała jego rozprawa jest próbą wykazania, że pewne poznanie naukowe jest możliwe. I. Kant, Krytyka czystego rozumu, oprac. R. Ingarden, Warszawa 1986.

${ }^{27}$ Cf. P.J. Fitzpatrick, Neoscholasticism, w: The Cambridge History of Later Medieval Philosophy, s. 845-848.

${ }^{28}$ W. James, Wola wiary, w: idem, Prawo do wiary, Kraków 1996, s. 49: „Empiryście jest obojętne, $\mathrm{z}$ jakich stron jego hipoteza pochodzi: mógł ją uzyskać nie przebierając w środkach; mógł iść za podszeptem namiętności lub za przypadkową sugestią; jeśli jednak cały tok myślenia nie przestaje jej potwierdzać, to mu wystarcza, aby nazwać ją prawdziwą”. S. 59-60: „Kiedy patrzę na zagadnienie religijne tak, jak się ono rzeczywiście przedstawia konkretnemu człowiekowi [--], wówczas ów nakaz, byśmy powstrzymywali serce, instynkty i odwagę oraz wyczekiwali - działając tymczasem mniej więcej tak, oczywiście, jak gdyby religia nie była prawdą - aż do dnia sądu lub do chwili, gdy intelekt i zmysły wspólnymi siłami wyszperają dosyć dowodów - ów nakaz, powiadam, wydaje mi się najdziwaczniejszym bałwanem wyprodukowanym w filozoficznej jaskini". 
Tymczasem, mimo widocznego historycznego związku nominalizmu Hume'a z postawami obojętnymi bądź wrogimi religii, sam nominalizm do takich poglądów nie musi prowadzić - jego pierwsi zwolennicy byli wszak teologami. Pomimo wszystkich różnic między sobą, trzy nominalizmy (Abelarda, Ockhama i Hume'a) są zgodne w tym, że za jedyne samoistne byty uznają jednostkowe konkrety poznawane na drodze empirycznej. W każdym z nich mamy też do czynienia z podobnymi konsekwencjami, z których najważniejszą jest ta, że nominalizm spłaszcza metafizykę: zamiast rozwiniętej hierarchii bytów ogólnych mamy konkrety i pojęcia, które o tych konkretach orzekają na sposób mniej lub bardziej ogólny.

U Ockhama takie stanowisko ma też konsekwencje teologiczne: Bóg stwarza poszczególne byty, w tym ludzi, takimi jakimi są, bez pośrednictwa natur ogólnych: natura ludzka w sensie ścisłym to zatem natura konkretnego człowieka. Kwestia zasady ujednostkowienia, za pomocą której natura communis, będąca niczym innym jak Bożą ideą, staje się „tym oto”, która tak bardzo nurtowała filozofów od czasów Boecjusza, staje się bezprzedmiotowa. Natomiast natura ludzka w ujęciu ogólnym nie jest niczym innym jak pojęciem wytworzonym przez człowieka po to, by móc intelektualnie ująć to, co wspólne wielu ludziom. Bóg jako absolut takiego nieprecyzyjnego narzędzia w ogóle nie potrzebuje swoim aktem stwórczo-poznawczym ujmuje każdego człowieka w całości jego bytowej charakterystyki, zarówno w tym, co charakteryzuje tylko pojedyncze jednostki, jak i tym, co wspólne dla jakichś ich grup, czy też dla wszystkich. Poznanie tego, co ogólne, traci zatem swój walor „wglądu w boże idee”, a staje się swego rodzaju intelektualną protezą, pozwalającą ludziom konstruować tezy ogólne za cenę zmniejszonej precyzji naszego poznania wymuszonej przez konstrukcję pojęć ogólnych na tyle nieostrych, by mogły orzekać o wielu jednostkach. Jest rzeczą oczywistą, że ktoś świadomy, w jaki sposób konstruowane są pojęcia budujące wiedzę, będzie jednocześnie zdawał sobie sprawę z jej hipotetycznego jedynie charakteru, obstawanie bowiem przy jej pewności byłoby bowiem przykładem pychy rozumu, tak potępianej przez Bernarda z Clairvaux ${ }^{29}$.

${ }^{29}$ Gerson, nominalistyczny teolog paryski z początku XV w., tak krytykuje realistyczne roszczenia do pewności poznania: „Sądzi on [Rajmund Lull], że przytacza dowody, dotyczące na przykład prawd wiary, będących przecież jedynie opartym na wierze poglądem świętych ojców, który uznawali za skuteczny w przekonywaniu tak zuchwalców jak niedowiarków. Nie da się przecież zrozumieć, jak ktoś wskutek takich argumentów mógłby wytrwać w wierze. [Ojcowie] widzieli bowiem, że mówienie takich rzeczy nie było zaszczytem, lecz raczej wystawianiem nas i naszej wiary na pośmiewisko pogan, którzy od dawna już umieli odróżniać takie argumenty od dowodów i uznawali je za sofistyczne dzielenie włosa na czworo. Dlatego też gdziekolwiek 
Jeśli tak, to koncepcja prawa naturalnego w takiej postaci, w jakiej przedstawił ją Tomasz z Akwinu, traci swoją dotychczasową podstawę ponieważ natura ogólna ma charakter hipotetyczny, wyprowadzanie z niej jakichkolwiek praw dokonywane być może w sposób arbitralny, gdyż metoda indukcyjna nie daje nam możliwości pewnego ustalenia, które ludzkie cechy mają walor powszechny, jako że jest dla człowieka, chociażby z uwagi na krótkość jego życia, zawsze niepełna. W efekcie każdy człowiek musi je wyprowadzać z własnej natury, kształtując sumienie w procesie jej poznawania. Wprowadzona przez Ockhama zmiana miała także inne, równie daleko idące konsekwencje dla teologii. Stosowana przez niego mistrzowsko (choć nie przez niego wymyślona) zasada ekonomii myślenia, zwana „brzytwą Ockhama”, wyeliminowała zeń część spekulacji scholastycznych o charakterze teoretycznym, ,żeby zrobić miejsce dla wiary" ${ }^{30}$, głosząc iż „nie możemy twierdzić, że jakieś zdanie jest prawdziwe lub utrzymywać, że istnieją jakieś rzeczy, bez przekonania wynikającego z oczywistości doświadczenia, objawienia lub logicznej dedukcji, albo z prawdy objawionej, albo ze zdań potwierdzonych przez obserwację"31. To miało dwojaki skutek. Z jednej strony Ockham opowiedział się za stanowiskiem widzącym w teologii przede wszystkim dyscyplinę praktyczną. Spór o to, czy jest dyscypliną teoretyczną czy praktyczną, toczył się mniej więcej od czasu pojawienia się teologii na uniwersytetach. Ockham, powołując się na Arystotelesa, uważającego, że za teoretyczną możemy uznać jedynie taką naukę,

święty Tomasz mówi o racjonalnych argumentach przytaczanych dla uzasadnienia prawd wiary, natychmiast je obala, aby nie sądzono, że są oczywiste” („[Raimundus] putat se demonstrationes adducere, utputa circa fidei articulos, quae non sunt nisi persuasiones a sanctis patribus, praesupposita fide, quas voluerant efficaces ad convincendum protervos et incredulos reputare, neque dari intelligi quod propter hujusmodi rationes persisterent in fide. Videbant enim quod hoc dicere magis erat nos fidemque nostram exponere derisioni infidelium quam honori, scientium tales argutiones a demonstrationibus longe esse, nec nisi sophisticas paralogizationes apud eos reputari; sicut sanctus Thomas loquitur ubicumque rationes introducuntur pro fidei articulis, quas inductas statim dissolvit ne putentur esse evidentes"). J. Gerson, Super doctrinam Raymundi Lulle, w: idem, Oeuvres complètes, wyd. P. Glorieux, t. 10, Paris 1973, s. 122 (tłum. moje - M.G.).

${ }^{30}$ Sformułowanie to pochodzi od Kanta, który umieścił je w prologu do drugiego wydania Krytyki czystego rozumu (B XXX,11). Ockham natomiast pisze tak: „Trzeba jednak zauważyć, że niekiedy z powodu niedoskonałości poznania intuicyjnego [- ] lub z powodu pewnych przeszkód wynikających ze strony przedmiotu, lub też z powodu innych trudności, może się zdarzyć, że nie można poznać żadnych, bądź można poznać tylko bardzo nieliczne prawdy przygodne dotyczące jakiejś rzeczy poznawalnej intuicyjnie”. W. Ockham, Prolog do „Ordinatio”, w: Wszystko to ze zdziwienia. Antologia tekstów filozoficznych z XIV wieku, s. 209.

${ }^{31}$ E. Jung-Palczewska, Wilhelm Ockham. Wprowadzenie, w: Wszystko to ze zdziwienia. Antologia tekstów filozoficznych z XIV wieku, s. 195. 
której celem jest sama wiedza, dowodził, wbrew m.in. Tomaszowi z Akwinu, że teologia nie spełnia tego warunku, albowiem jej celem, zewnętrznym wobec poznania, które zostaje mu podporządkowane, jest dążenie do zbawienia, czy też prowadzenie ludzi do Boga ${ }^{32}$. Z drugiej strony, co było w jakiejś mierze konsekwencją pierwszego skutku, wzmocniony został akcent kładziony na indywidualne doświadczenie Boga: praktycznie rozumiana teologia, odwołująca się bezpośrednio do prawdy objawionej i doświadczenia oraz wskazująca na praktyczny cel refleksji teologicznej, cechuje się postawą życzliwszą wobec mistycyzmu (trudno się dziwić, że np. Gerson z taką aprobatą cytuje Bonawenturę czy Ryszarda od Świętego Wiktora, skoro podkreślają oni te same aspekty teologicznego poznania) czy też nowej pobożności, która zaczęła się rozwijać nad dolnym Renem właśnie wtedy, gdy nominalizm święcił największe tryumfy w Paryżu ${ }^{33}$.

Skutki takiego nastawienia są godne podziwu. Nominalistyczna teologia, np. Gersona, rektora uniwersytetu paryskiego z czasu Soboru w Konstancji (w którym brał udział), przyjmuje taki właśnie, praktyczny i skupiony na doświadczeniu wiary, ideał i podejmuje próbę reformy, ratunek przed czczymi spekulacjami widząc w rygoryzmie terministycznej logiki.

W sposobie oznaczania i przedstawiania intelekt postępuje na różne sposoby, nie przez zmyślenia i kłamstwa, gdyż mówi Filozof, że abstrahowanie to nie kłamstwo, lecz różnica ta wywodzi się z rzeczy zrozumianych w taki czy inny sposób. W ten sposób logicy, których inni nazywają terministami czy nominalistami, trafniej prowadzą do rzeczy niż zwolennicy formalitates. Wreszcie, skoro się założy prawdziwość wiary, którą teolog wyznaje i poszukuje, nie ma łatwiejszego przedstawienia czy objaśnienia niż przez logikę, czy to w kwestii predestynacji i potępienia, czy braku i negacji, czy relacji zewnętrznych; tak jest z powszechnikami realnymi bądź myślnymi, $\mathrm{z}$ istnieniem $\mathrm{i}$ istotą, $\mathrm{z}$ rozróżnieniem na quod est $\mathrm{i}$ quo est, $\mathrm{z}$ działaniem Boga mierzalnym albo niezmierzonym, koniecznym albo przygodnym, z różnicą formalną i materialną, tak też z zapełnieniem świata podobnymi jednostkami, o których powiedziano gdzie indziej, itd. ${ }^{34}$

W swoich tekstach Gerson przedstawia zalecenia wypływające $\mathrm{z}$ analizy błędów niektórych teologów realistów ${ }^{35}$, które to błędy zosta-

${ }^{32}$ Cf. M. Olszewski, o praktycznej bądź teoretycznej naturze teologii, Kraków 2002, s. $402-405$.

33 „Gerson podjął także polemikę z dominikaninem Mateuszem Grabow w obronie Braci Wspólnego Życia. Utrzymywał, że praktyka doskonałości chrześcijańskiej jest dostępna nie tylko tym, których wiążą zakonne śluby czystości, ubóstwa i posłuszeństwa, lecz na równi wszystkim ludziom". M. Jakubowska, Wstęp, w: J. Gerson, o teologii mistycznej, oprac. eadem, Kęty 2012, s. 10.

${ }^{34}$ J. Gerson, Super doctrinam Raymundi Lulle, s. 127-128 (tłum. moje - M.G.).

35 „Chcieć więc dowodzić prawd wiary, szczególnie zaś tych, które odnoszą się do 
ną potem przez krytyków przypisane scholastyce w ogóle i napiętnowane, wszelako bez wskazania na pierwotnego autora tych zarzutów. Być może spowodowane to było tym, że późniejsza krytyka, np. wspomnianych już Mikołaja z Kuzy i Erazma z Rotterdamu, dokonywana była z pozycji niechętnych arystotelizmowi: neoplatońskich u Mikołaja, a cyceroniańskich u Erazma, i jej przedstawiciele nie chcieli niczego zawdzięczać ludziom, których uważali za swoich przeciwników. Ostatecznie nominalizm został ponownie zapomniany w XVI w. po tym, jak Francisco Suarez, podejmując próbę odnowienia teologii, zwrócił się po inspirację do realistów: św. Tomasza z Akwinu i Jana Dunsa Szkota ${ }^{36}$.

Trudno się w związku z tym dziwić, że kiedy nominalizm został powtórnie odnowiony przez Hume'a, a potem upowszechniono go w dziewiętna-

ludzkości, jest zupełnie lekkomyślnym i zuchwałym wystawianiem naszej wiary na pośmiewisko niewiernych, ponieważ jak twierdzi ten sam autor, [cytowany] przez Lulla pod koniec jego dzieła, chcąc odpowiedzieć na pytanie ukryte, lecz trafnie go uderzające: «jeśli nie uwierzycie, nie zrozumiecie». Dlatego też mówi Apostoł: «my głosimy Chrystusa ukrzyżowanego, który jest zgorszeniem dla Żydów, a głupstwem dla pogan», i dalej: «przyszedłszy do was, bracia, nie przybyłem, aby błyszcząc słowem i mądrością głosić wam świadectwo Boże»; i jeszcze raz: «Baczcie, aby kto was nie zagarnął w niewolę przez tę filozofię», która mianowicie posługuje się jedynie argumentami naturalnymi. Albowiem mądrość chrześcijańska jest tym, co pokazuje głupotę światowej mądrości, w tym mianowicie, że filozofowie odbierają wolność Bogu, jakby z jej powodu miał się stać zmienny. O tej to wolności uczy także prawda chrześcijańska, że nie jest poruszana przez zmiany, lecz będąc stała, powoduje, iż wszystko się porusza, nawet wróble zlatujące na ziemię i liście drzew. Jeden zaś biskup czyni wiele, nie tyle jako jeden spośród nas, do których jest porównywany, lecz w odniesieniu do rozmaitych rzeczy, tak jak ta sama siła słońca roztapia wosk i utwardza glinę. Dla zrozumienia tego, co wyżej [omawiano], można dodać jeszcze inne rozróżnienie dotyczące porządku, czyli porównania stworzeń do Boga. Tak oto nasz intelekt porównuje stworzenie do Boga najpierw jako odwiecznie [przez Niego] poznawane; po wtóre, jako mające być przez Boga wytworzone w czasie, lecz jeszcze nie wytworzone; po trzecie, jako istniejące realnie, umieszczone we właściwym rodzaju. Pierwszy byt starożytni metafizycy nazywali bytem poznanym [esse cognitum] lub przedmiotowym [objectale], czy też spekulatywnym; drugi byt nazywali bytem poznanym albo przedmiotowym, albo spekulatywnym, albo wytworzonym, albo idealnym, albo wreszcie praktycznym; trzeci byt nazywali realnym albo spowodowanym [causatum], albo ustanowionym $\mathrm{w}$ istnieniu. To rozróżnienie podobnie nie znajduje wyjaśnienia $\mathrm{z}$ uwagi na miejsce, [i pozostaje] niejasne, powodując niezliczoną ilość nieprzezwyciężonych i fantastycznych błędów; nie na próżno bowiem mówi się, że dialektyka jest sztuką sztuk i drogą do wszystkich zasad metafizyki, choć przez niektórych filozofów logicy nazywani są terministami i początkującymi. Prawda jednak, która znajduje się w rzeczach, nie może być przedstawiona w sposób zrozumiały bez słów i terminów, nie wymyślonych, lecz ujętych prawdziwie i rzeczywiście różnych, dzięki którym dochodzimy do samych rzeczy". J. Gerson, Super doctrinam Raymundi Lulle, s. 125-126 (tłum. moje - M.G.).

${ }^{36}$ Cf. J.A. Trentman, Scholasticism in the seventeenth century, w: The Cambridge History of Later Medieval Philosophy, s. 822-825. 
stowiecznym scjentyzmie, podzielającym Hume'owską rezerwę wobec religii (łagodnie rzecz nazywając), budził u teologów już tylko negatywną reakcję jako narzędzie myśli wrogiej wobec wiary i religii, zasługujące na potępienie na równi z innymi modernistycznymi nowinkami ${ }^{37}$; z kolei odnowiony tomizm nie miał dla korzystającej z nominalizmu filozofii i nauki nic do zaproponowania. Badania nad filozofią średniowieczną, rozpoczęte w końcu wieku XIX, długo skupiały się przede wszystkim na poglądach myślicieli XII i XIII stulecia i jeszcze u Étienne'a Gilsona, piszącego swoją historię myśli chrześcijańskiej w wiekach średnich w połowie XX stulecia, odnaleźć można przekonanie, że wiek XIV to już okres schyłku i wyczerpania twórczych możliwości tej filozofii ${ }^{38}$. Mimo iż pogląd ten został zakwestionowany przez następne pokolenia badaczy, którzy okres świetności scholastyki przedłużają obecnie co najmniej do czasów Czarnej śmierci (1346-1349), wiedza ta z wielkim trudem przebija się poza wąskie środowisko historyków filozofii średniowiecznej. W szczególności zauważalny jest brak prób nawiązania do nominalizmu teologicznego z XIV i XV w. ze strony środowiska teologów, którzy z uporem widzą w myśli Ockhama jedynie źródło zepsucia ${ }^{39}$; to sprawia, że mimo najlepszych chęci, teologia z jednej, a filozofia i nauka z drugiej strony nie są w stanie odzyskać wspólnego języka.

Jest to o tyle zdumiewające, że potrzeba znalezienia takiego języka zgłaszana była przez teologów od dawna. Rozmaite próby opracowania nowego języka dla teologii zostały zintensyfikowane po II Soborze Watykańskim. Obejmowały one całą paletę działań: od dość nieśmiałych, takich jak wzbogacenie neotomizmu o elementy wzięte z innych szkół filozoficznych, np. fenomenologii ${ }^{40}$, po radykalne, takie jak próba uwolnienia refleksji teologicznej od języka neoplatońsko-arystotelesowskiego i zbudowanie jej na innych podstawach ${ }^{41}$. Nie było jednak wśród tych prób nawiązania do tra-

${ }^{37}$ Syllabus, dołączony do encykliki Piusa IX Quanta cura z 1864 r., obejmował 80 błędnych tez teologicznych, filozoficznych i dotyczących życia społecznego, m.in. panteizm, naturalizm, racjonalizm, liberalizm. Cf. Religia. Encyklopedia PWN, red. T. Gadacz, B. Milerski, t. 9, Warszawa 2003, s. 167.

38 „Próba oczyszczenia tomizmu i wyeliminowania zeń Tomasza z Akwinu [--] w czternastym wieku doprowadziła do upadku tomizmu w szkole dominikańskiej oraz szkotyzmu w szkole franciszkańskiej. Krótko mówiąc, próba ta spowodowała upadek teologii scholastycznej trzynastego wieku". É. Gilson, op. cit., s. 420.

${ }^{39}$ Cf. np. L. Wiśniewski OP, Blask wolności, Kraków 2015, s. 11.

40 Syntetyczne ujęcie rozmaitych wariantów neotomizmu daje Mieczysław Gogacz, Tomizm egzystencjalny na tle odmian tomizmu, w: W kierunku Boga, red. bp B. Bejze, Warszawa 1982, s.14-19.

${ }^{41} \mathrm{~Np}$. dialogizm czy filozofia dramatu wypływające z myśli Hermanna Cohena, Martina Bubera i Franza Rosenzweiga, której ważnym przedstawicielem w Polsce był Józef Tischner. Cf. Religia. Encyklopedia PWN, t. 4, Warszawa 2002, s. 47-48. 
dycji via moderna, mimo jej bogatego i ciekawego dorobku od Ockhama do Gersona. Teologia, ignorując nominalizm, sama zdaje się przyczyniać do dechrystianizacji europejskiej kultury intelektualnej, przyczynia się bowiem do dalszego rozchodzenia się języków nauki i teologii. Jeśli chce być zrozumiana przez świat współczesny, musi uwolnić się od gorsetu pseudoobiektywnego ujęcia realistycznego. Tradycja nominalistyczna w teologii, przez stulecia atakowana lub ignorowana, zasługuje na to, żeby dać jej szansę. Może odwołanie się do niej nie będzie cudownym lekarstwem, ale lekceważenie takiej możliwości dialogu z filozofią i nauką, jaką ta tradycja oferuje, jest lekkomyślnością.

\section{Satire against Slothful Theologians, or Certain Philosophy Lessons Unlearned for 600 Years}

The participants of world outlook disputes in Poland often agree as regards one thing: the progress made by modernization is simultaneously the progress of Dechristianization, while all other issues vanish in the turmoil produced by the absence of a joint language that would make it possible to comprehend the arguments of the other side. The fault for this state of affairs lies with theologians who do not want to or cannot communicate in the language of nominalism, universally accepted by the exact sciences and a considerable part of philosophy. This is strange considering that in its past theology was capable of rapidly adopting and adroitly applying assorted philosophical languages, including that of nominalism, to whose origin and early development theologians contributed significantly during the Middle Ages. An analysis of relations between mediaeval Christianity and nominalism demonstrates how, after initial failures caused by attachment to Platonic and Aristotelian realism, theologians learned how to benefit from the new language; it also shows what was the reason why nominalism was abandoned and why no attempts were made at regaining it despite the actual or possible profits of its use.

Translated by Aleksandra Rodzińska-Chojnowska 